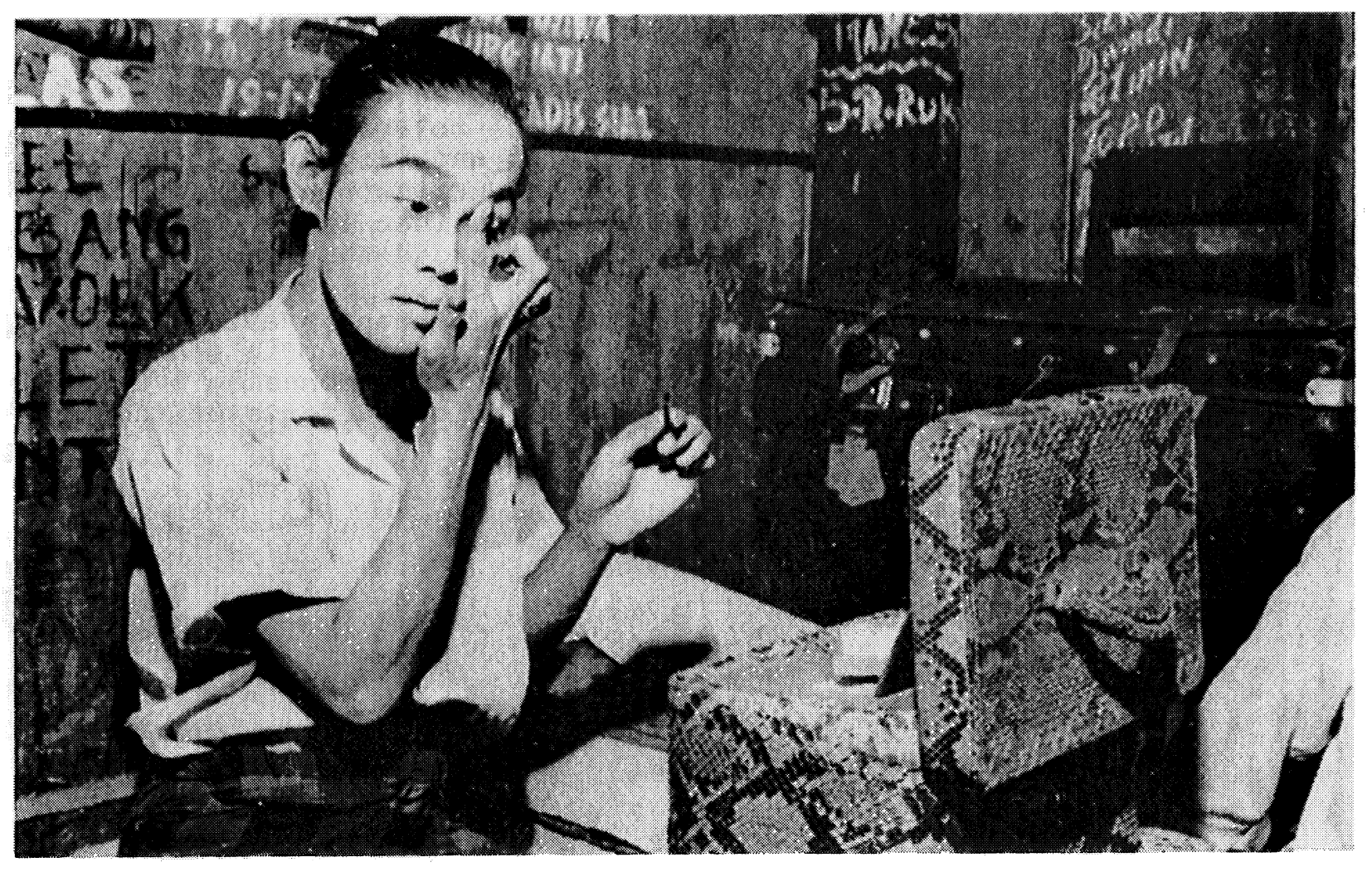

The actor playing Susanna in "Untung Surapati" makes up backstage.

All photos illustrating the following article are by James Peacock 


\section{ANTI-DUTCH, ANTI-MUSLIM DRAMA AMONG SURABAJA \\ PROLETARIANS: A DESCRIPTION OF \\ PERFORMANCES AND RESPONSES}

James L. Peacock

The center for those dramatic performances called ludruk is the city of Surabaja, on Java's northeast coast. Ludruk is a popular form of entertainment, watched and enacted there almost entirely by proletarians. I I estimate that at the time of my observations in 1963 there were about two hundred ludruk troupes in Surabaja, most of them semi-professional; and there were five commercial theaters in Surabaja which opened nightly, each attracting every evening an audience of perhaps four hundred souls.

Though Surabaja is the center of ludruk, there are ludruk troupes originating from areas as far east as Banjuwangi (on the tip of Java closest to Bali) and as far west as Kediri (bordering the central Javanese culture area). Ludruk troupes from these places as well as from Surabaja travel all over Java and even to other parts of Indonesia. There also exists a drama called ludruk on the island of Madura, across the bay from Surabaja.

The form of ludruk to be discussed here was apparently invented by Tjak Gondo Durasim in the late nineteen-thirties. Durasim had played clown in an older form of ludruk called Besut, and he organized the first troupe to play in a downtown theater and perform full-fledged drama with chanacters varying according to the story. (Ludruk Besut stories all featured the same characters--the clown, Besut, his wife Asmunah, and Asmunah's uncle, Djamino.) In its present form, a ludruk performance at a commercial theater such as the THR (Taman Hiburan Rakjat) lasts from eight in the evening until slightly after midnight and includes an opening dance, a clown song, clown prologue, melodrama, and songs by transvestite males between the scenes of the melodrama.

In this paper I treat only the melodrama, of which ludruk participants distinguish several types: tjerita rumahtangga (domestic stories, portraying attempts of heroes and heroines to marry and to solve their family problems), tjerita revolusi (stories about the Indonesian revolution, featuring such actions

1. Some might quibble at the precision of the word "proletarian." By it I mean working-class people who live in kampung and have some degree of class-consciousness in that they apply to themselves labels such as "kaum buruh." 
as guerilla warfare against the Dutch), and tjerita pahlawan (stories about legendary Madurese or Javanese heroes of the colonial era). Of the eighty-two stories which I saw performed, thirty-six were of the first type, eight of the second, twentyfive of the third, and the others were of various kinds not fitting any of the three categories named.

The most famous and popular tjerita pahlawan were four: "Pak Sakera," "Sarip Tambakjasa," "Sawunggaling" and "Untung Surapati." The title of each story is the name of its hero. They are the "famous four" of the ludruk hero pantheon and are perceived by the participants as being in some way within the same "league" (thus, on the wall of the THR theater were hung together four plaques depicting the four heroes). Since the four go together, and since I have not presented detailed materials on these dramas elsewhere as I have with the other types of ludruk stories, ${ }^{2}$ it seems appropriate to devote this article to their description.

The reader will immediately detect relationships between the stories. "Pak Sakera" and "Sarip Tambakjasa" form one pair, featuring Madurese heroes of similar character, some almost identical scenes, and similar outcomes. "Untung Surapati" and "Sawunggaling" compose another pair, portraying Javanese heroes with similar aims who may have existed during the same historical period (one account has it that Sawunggaling actually aided Untung Surapati in a fight against the United East India Company in 1706). The theme linking all four stories is that of anticolonialism or "the Dutch as villain," but this theme is overshadowed by an anti-Muslim theme in the two Madurese stories. This may derive partly from the fact that ludruk spectators and actors are almost without exception abangan (anti-Muslim or inactive Muslim). Indeed, going to the mosque and taking part in ludruk seem to be mutually exclusive actions since ludruk participants rarely, if ever, go to the mosque (or do the prayers, abstain from pork, or go to Mecca), and santri consider it sinful to act in or watch ludruk, mainly because ludruk female impersonators mix female and male elements publicly on the stage. (A number of female impersonators in ludruk were raised by strict santri parents and, upon deciding to rebel, chose the path of assuming women's roles on the stage.) Although virtually all ludruk participants, Javanese or Madurese, are abangan, the abangan-santri schism rarely appears in the dramas except in Madurese stories, which usually attract large Madurese audiences. In Javanese stories Islam is rarely mentioned, and when it is, as with the Muslim missionary who urges Sawunggaling to

2. Detailed analysis of tjerita rumahtangga and tjerita revolusi can be found in my book, Rites of Modernization: Symbolic and Social Aspects of Indonesian Proletarian Drama (Chicago: University of Chicago Press, 1968), Chapters 8 and 9. 
fight the Dutch or the King of Tjirebon referred to in "Untung Surapati" as being "like a Kijaji," it is not particularly denigrated. Thus, the abangan-santri schism--at least to judge from ludruk--may be stronger among the Madurese than among the Javanese.

On the other hand, this contrast between the Madurese and Javanese stories may involve differences more social than religious. The Javanese stories are essentially loyal to the native hierarchy whereas the Madurese express wild protest against the status quo. The Javanese stories are fairy-tales of the classical type--the peasant boy who saves the kingdom and who may turn out to be a King in disguise. They depict commoners joining royal personages to defend the homeland against foreign invaders. They are cast in a legendary time only a step removed from the mythical kingdoms of the wajang. By contrast, the Madurese tales are more contemporary, do not "focus" socially much above the wedana level, and are vehemently opposed not only to the Dutch but also to the locally rich and respectable. What is wrong with the hadji or the pious elder brother is what is wrong with the lurah and other officials: they are of high status, hypocritical, greedy, cowardly, and make use of their position to oppress the poor. Thus, the protest expressed by such wild men as Sarip and Sakera may be not so much against Islamic piety itself as against elite status which involves among other things piety (especially since the pious tend to be wealthy moneylenders and merchants). It is interesting that these protests are dramatized in village settings but are enacted and watched by persons who have left their villages, though in many cases not too long ago. Perhaps the status of being independent of the village, yet still associated with it in memory or through kin or acquaintances, helps account for the violent and freewheeling spirit of protest against the rural ruling classes expressed in these Madurese stories. It is interesting that the two Madurese dramas project a rawer, more violent tone than do the two featuring Javanese heroes. That difference reflects Surabajan stereotypes (which are not, I think, without accuracy) of contrasting Madurese and Javanese character and culture.

I shall not present texts or scripts of the four hero stories, but outline-descriptions of live performances of each which I witnessed. The descriptions are fairly direct transcriptions from portions of my fieldnotes. Each of the performances was observed during an evening, at which time the notes were taken, and from these I wrote a description of the whole performance, usually the morning after it occurred. From four total performance descriptions constructed in this manner I have abstracted those portions dealing with the four melodramas and the audience responses to them. ${ }^{3}$

3. I usually place such responses in brackets, after the description of on-stage action to which the response relates. Some of these audience responses were recorded by me but 
I was able to follow the Indonesian language dialogues of these performances accurately, to get the gist--but not the subtleties--of many of the ngoko Javanese dialogues, and to comprehend the Madurese dialogues not at all. (Since the larger study in which I was engaged dealt only with the linkages between ludruk and Javanese society, I gave only marginal attention to Madurese culture during my stay in Surabaja.) "Sawunggaling" and "Untung Surapati" were rendered in the first two of these languages, "Pak Sakera" and "Sarip Tambakjasa" in all three--actors using the language appropriate to the role they were playing--so I employed an interpreter, a linguistically gifted Javanese, who sat beside me at each performance and gave a running transiation of what was said while $I$ concentrated on the on-stage action. The result of the interpreter's running account, my own observations, and the recordings of the audience responses is, I believe, a reasonably accurate outline description of what went on at each of the four performances.

\section{Pak Sakera}

[As performed by the ludruk troupe Mari Katon at the PBRI theater on March 7, 1963.]

CURTAIN OPENS FOR FIRST SCENE. It is sometime during the early nineteen-hundreds. Pak Sakera, a Madurese, formerly employed as a foreman at a sugar factory in Pasuruan, his face painted bright red to signify his ferocity, is standing on the right side of the stage. A tall bearded Dutchman stands on the left. Neither speaks. A voice from off-stage says that Pak Sakera tried to make peace with the Dutch, but the Dutch would not heed, so finally Pak Sakera was forced to take revenge. Suddenly Sakera erupts into action, slicing the Dutchman with his sickle. The Dutchman utters the first words of the performance: "Aaaaaaaaagh!"

most, especially the verbal comments, were recorded by Javanese high school students. I had arranged for three high school (S.M.A.) students to accompany me to ludruk performances each night during a period of several weeks. Each student sat in a different class section. Each was instructed to record any audience response he heand in whatever language it was uttered. I translated these recordings of responses (which were usually in ngoko Javanese), checking words I could not understand with a Javanese informant. Since the students were not fluent in Madurese, Madurese persons' responses to the performances are doubtless underrepresented here, which is unfortunate since many Madurese spectators attended "Pak Sakera" and "Sarip Tambakjasa." The reader should keep in mind that virtually all audience responses which $I$ cite issued from Javanese persons. 
SCENE TWO. Pak Sakera is now in the prison of Kalisosok in Surabaja, because he killed the Dutchman and because he had been accused of stealing funds. (He was framed by a village chief [Iurah] and his assistant [tjarik], who had cheated Sakera and were responsible for getting him fired by his Dutch boss from his job at the sugar factory.) As the curtain opens, a Madurese friend of Sakera's, Satia, is talking to a prison guard. Suddenly the gamelan breaks into a lively tune, "Djuladjuli." Satia starts dancing in rhythm to the music, popping his head from side to side in time with the drum-beats of the gamelan. The prison guard gets seduced into dancing with Satia, popping his head from side to side in rhythm with satia's. Another guard sees the action of the first, mutters a contemptuous comment. The first guard, startled, stops, but then starts up again.

Amat, a clown, appears, dressed as a prison guard. [He is greeted by great laughter from the audience.] Amat's face stares stupidly ahead, looking neither to left on right, unsmiling. Then he flutters his eyelids. A fat Dutchman appears, with much gold braid and other decorations on his uniform, blustering out pompous guttural instructions in Indonesian to Amat. He waits for Amat to answer. Amat utters a crude Surabaja Javanese word [laughter]. The Dutchman is infuriated. He gives Amat some more orders but Amat suddenly gives his shoulder a comradely shove [great laughter]. The Dutchman is further enraged. Amat leaps away, smiles tensely. Now the Dutchman commands Amat to bring in the prisoners. He does so, acting tough (incongruously so, since he is puny in appearance and ordinarily passive in manner); he makes them kneel to him, rattles his gun at them. The Dutchman bustles up, pats Amat on the shoulder. "Ah yes," he says, "That is good. You must show your power." Amat brings in more prisoners, then contemplates his rifle: "This gun won't do any good, since I load it with pepper. This is an old pepper!" [laughter]. Now the Dutchman commands Amat to bring in Pak Sakera. "Don't want to (tak maaaaaau)," whines Amat, with a horribly pained expression on his face. The Dutchman insists, and Amat goes to get Pak Sakera. Sakera, with his face red, bushy mustache and black villager's clothes, swaggers in, holding a whip. ["Pak Sakera is truly cruel (kerenge)"].

The Dutchman quizzes Sakera about the places in Surabaja where he has lived. Sakera insists on translating the place names into garbled and hideous sounds. The Dutchman asks him about Djembatan Merah, the "Red Bridge," from which busses depart in Surabaja, and Sakera mispronounces "Djembatan Merah" as some incomprehensible sound, "D... ." "Djembatan Merah!" shouts the Dutchman, correcting Sakera. "D...!" shouts Sakera, louder. "Djembatan Merah!" screams the Dutchman. "D...!" screams Sakera, much louder. Finally Sakera shouts the Dutchman down. The Dutchman mutters "Yes," and writes something in a notebook, turning to Amat and pompously stating that Sakera is a difficult 
fellow. He turns back to Sakera and engages in another shouting duel with him, then again and again. Finally, the Dutchman orders Amat to take Sakera away. "Why don't you treat him tough the way you do the others?" he asks Amat. "The others were tiny and weak," whines Amat.

SCENE THREE. A man leaps into Sakera's path. It is Satia, Sakera's friend; they greet each other violently. The friend tells Sakera of illicit goings-on between Sakera's second wife, Marlina, and his nephew, Brodin. Sakera, angry, decides to escape from prison in order to straighten things out at home.

SCENE FOUR. Pak Sakera's first wife, Mbok Sakera, is at home, seated with legs spread wide apart, hands on hip, a loud voice, and a tough manner. She is Madurese. Mbok Sakera is scolding Brodin for gambling. "You can't even win," says she contemptuously. Brodin, in a bright shirt, a dandy, sits passively. [Spectators scream at Mbok Sakera: "O Samson!" (a cry often directed at tough female characters). "She has a face like Ghandi!" "Her walk!" "She doesn't walk, she marches," says a woman. Another woman, who sells fish in the market at Gresik, says of Mbok Sakera, "Wow! She talks like a real Madurese." Madurese are always portrayed in ludruk, and are regarded by Surabaja Javanese, as kasar--crude--in speech, manner, and appearance.]

Sakera's second wife, Marlina, enters. She is Javanese, refined (alus), thin, neatly dressed in high-quality kain batik in sharp contrast to Mbok Sakera, who is sloppily and cheaply dressed and keeps scratching her belly. (Mbok Sakera and Marlina are enacted by men, as are all women's roles in ludruk.) As Marlina enters Brodin grins, showing gold teeth, and pulls his cap over his forehead. Marlina says she loves Brodin. Brodin sings a Madurese song to her, and she sings a Javanese song to him: "Think, think, think, but the one you think about feels nothing." She says to Brodin, "If you were to die, I should feel sad." Brodin asks, "Why? If you die, I'll just grab another." [Various audience reactions accompany this dialogue. Somebody asks Marlina, "Is your husband Sakera or Brodin?" Somebody says to Marlina, "If she sees a handsome man, her eyes switch his way." Somebody shouts at Brodin, "Don't you dare fool with Sakera's wife! He'll break your neck--but you can't keep your hands off!" About Brodin someone explains, "This is Brodin, Sakera's nephew. Later he'll be killed." To Marlina: "This is the rainy season. Don't wear your hair so fancy; it'll come undone with all your fooling around. Your neck will come loose too (i.e., be cut off by Sakera)."] Brodin and Marlina embrace; Brodin wipes Marlina's face. [A spectator screams, "Fuck (diantjuk)!".] Brodin asks Marlina to give him jewels. [Someone laughs, "Ha-ha, she brought a big bracelet."] Brodin and Marlina touch each other, and a person comments, "Messing around--there you have it." Brodin tells Marlina she 


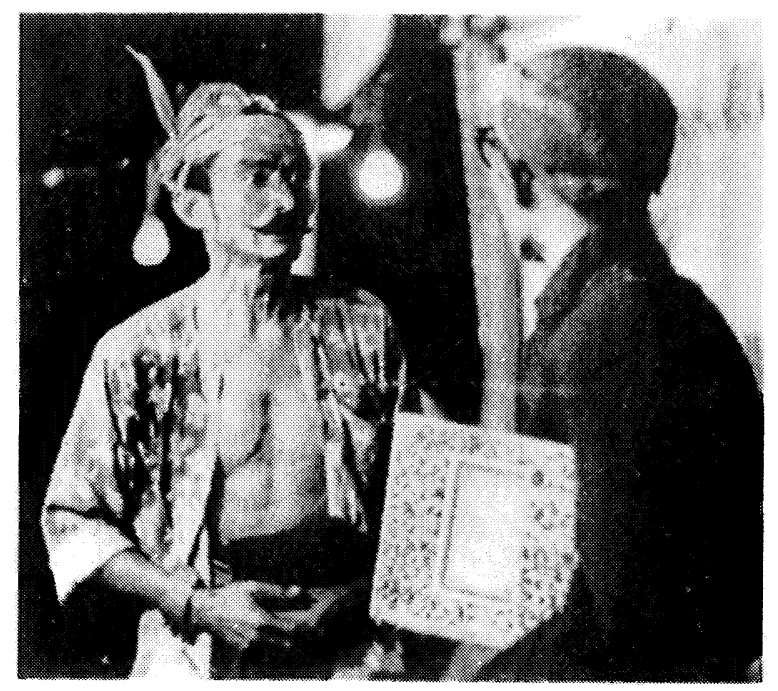

Satia talks to a prison guard.

Pak Sakera diverts the thrust of Mbok Sakera's knife.

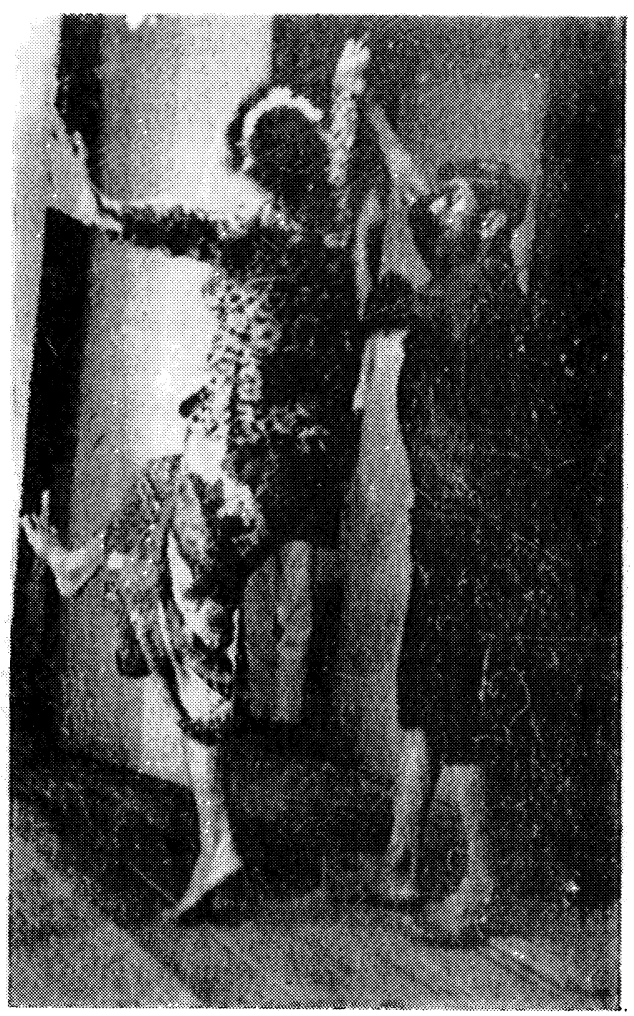


ought not to wear such a huge chignon. ["she's certainly a show-off," says a spectator. "She has a pretty face--but you can't sleep with her." (This presumably alludes to the fact that Marlina is a man.)]

At this point Pak Sakera, who has been standing outside, observing, throws some rocks through the window. The lovers are disturbed, but resume their activity, the girl caressing the male (it is never the revense in ludruk). Rocks are thrown again. They stop briefly, resume again. Repeat. ["Nice-those two don't feel a thing even when someone's peeking."]

Pak Sakera bounds in; Brodin flees. Sakera raises his sickle to kill Marlina. ["Who's playing Pak Sakena? Not Salimin. Fine acting." "Who plays Brodin?"] Marlina kneels to ask forgiveness. ["Ask him to forgive you! Ask him to forgive you! You want to live!"] Mbok Sakera bursts through the door, brandishing a huge knife, and screams, "What are you doing, Pak Sakera, you son of a bitch?" ["That woman is too wild for a man to dare get smart with her!"] Mbok Sakera rushes at Pak Sakera for the kill. He grabs her wrist and diverts her thrust toward the wall. Again and again she thrusts and he parries, so that their fight turns into a dance, Pak and Mbok leaping up to the wall together, he grasping her wrist, the two following her knife's thrust. Finally she slaps her knife back into her sash, glares contemptuously at Pak, scratches her belly, and leaves.

SCENE FIVE. Pak Sakera accosts Brodin, who is gambling, and slits his throat with his sickle.

SCENE SIX. Amat, who earlier played the prison guard, and Slamet, another clown, appear. They are night watchmen in a village, and each is beating a bamboo tube as they make their rounds. Amat always hits one too many beats in the rhythm's sequence; Slamet keeps trying to teach him, but Amat keeps hitting an extra beat anyway. [Each time he does so, the audience roars with laughter.]

Suddenly Amat and Slamet come upon Brodin's body; their bamboo-beating stops short of completing a sequence. Amat says, "Somebody's dead--that means 'dead.'" Amat perceives that Brodin's gambling winnings are on his body, and dives for the money, Slamet warns him, "Suppose I tell the police about this? When people are responsible for a body, they mustn't pick up money that's on it." ["Hurry and report it to the police! Don't take that money! You'll get blamed by the police!"] Amat throws the money down and Slamet dives for it. "Waaah," says Amat, frustrated.

SCENE SEVEN. The tjarik who had originally caused Sakera to lose his job walks by. Sakera wheels and slashes his throat. 
Pak Sakera kills Brodin.
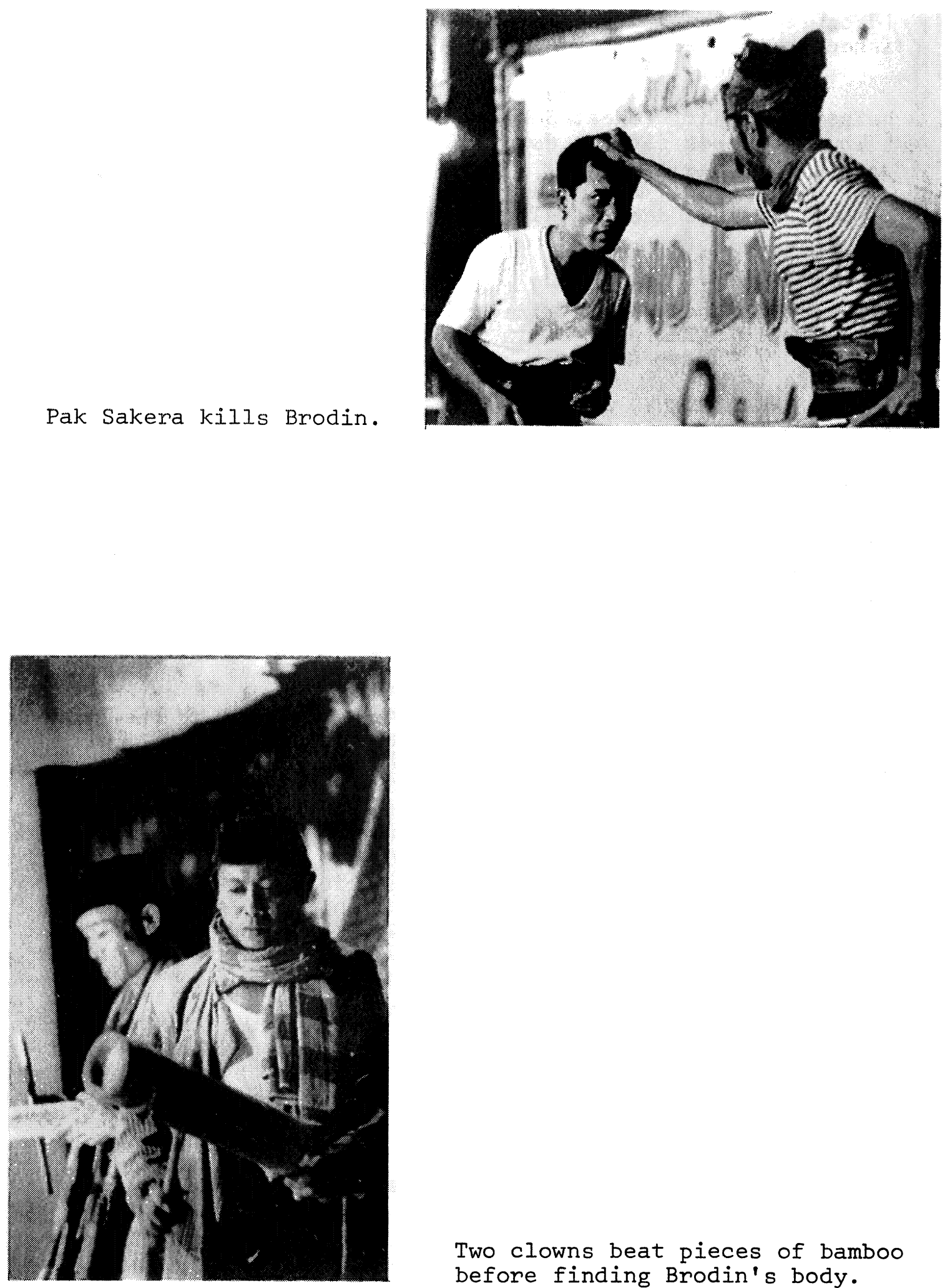

Two clowns beat pieces of bamboo before finding Brodin's body. 
["You're so savage, Pak Sakera!" "Good Lord, the man is punished so savagely!"]

SCENE EIGHT. Sakera comes to the house of the lurah who helped the tjarik cheat Sakera. He slits the lurah's throat. ["This one dies sitting down."]

SCENE NINE. Amat and slamet run to the tjarik's house to report Brodin's death, only to discover the tjarik's body.

SCENE TEN. Amat and Slamet run to the lurah's house to report Brodin's death, and there discover the Iurah's body. They are so. shocked that they jump. ["Ha hahahahaha, look at them jump!" "There's been a lot of killing. What hit this one?"I]

SCENE ELEVEN. Since the lurah and his assistant are dead, Amat and Slamet go over the list of officers in the administrative hierarchy to see who is still alive. The mantri polisi! They go to his office. There they sit respectfully on the floor as he asks them questions (this was the proper posture under Dutch rule). Amat answers the first one in English, "Hello." The mantri asks Amat's name. Amat whines, "Kulaaaaaa Amat ( $I^{2} m$ Amat)" in Javanese, then "What's yours?" in English. The mantri, shocked, jumps back. Amat leaps from his submissive floor position and gives him a shove, grinning.

SCENE TWELVE. The police have sent Amat to the house of a hadji by the name of Jasit, to procure his help in catching Sakera. Amat enters the house, brazenly walks past the hadji's outstretched hands into the arms of the hadji's wife, grasping her as if she and he were intimates (thus mocking Muslim sexual piety). After this, Amat produces a giant income tax form and begins narrating at length all the money that the hadji owes. The hadji, who like all santri stereotypes in ludruk is very stingy, walks to and fro in great anxiety. Finally the mantri polisi walks in. The hadji rushes fearfully up to him, asking him how much it is he owes the government. "Taxes?" asks the mantri, "You owe none." Amat meanwhile has gone outside. The mantri informs the hadji that his reason for coming is to get the hadji to help catch Sakera.

SCENE THIRTEEN. Jasit and another hadji, Bakri, have been asked to help fight Sakera though both were once his friends; they have been tempted by the police offer of a reward if they help catch him, and accordingly now appear at the mantri's office. Bakri and Jasit have long been bitter enemies due to a property dispute. Asked to cooperate in catching Sakera, they want to fight instead of shaking hands. ["My goodness, the hadji don't speak after a quarrel. The hadji have fought about property until they are not on speaking terms."1. The mantri's clerk has to threaten them with a pistol in order to force them 
to shake hands. Each then tries to crush the other's hand. The clerk points a pistol at their hands, and each relaxes exaggeratedly, falling into a pose of total unconcern. When the clerk turns away, they try to crush each other again, and the scene is repeated a few times.

SCENE FOURTEEN. The two hadji meet alone. They argue because Jasit is willing to kill Pak sakera in order to get the Dutch government reward, which he will use to buy new stalls in the market. Bakit, still Sakera's friend, tells Jasit that Sakera killed the lurah, tjarik, Brodin, and the Dutchman in just revenge. But finally the two agree to set a trap for Sakera in order to get the reward.

SCENE FIFTEEN. Jasit goes to the house of a modin who happens to live near a cave where Sakera is reputedly hiding. The modin's daughter has just come of age, and he is holding a celebration. Jasit asks the modin to hold a dance (tandak) during the celebration and invite Sakera, for it is known that Sakera has a weakness for tandak. The pious modin is greatly against giving the tandak, for it is sinful. He finally agrees when Jasit threatens government punishment if he refuses. Then he begins to like the idea of having the tandak, starts recalling how fine the tandak were during his youth in Gresik, and licks his lips in memory of the palm wine he used to drink in Tuban. [AIl of this evokes a flurry of comments from the audience alluding to illicit drives hidden under the modin's piety. A bricklayer, laughing, says, "My goodness, the modin knows about tandak, just like that!" Another: "The modin likes to go to the whores, I think."]

SCENE SIXTEEN. The celebration and tandak are in full swing. Dancing girls keep trying to tempt the pious modin to put the tandak cape on his shoulders and get out on the floor with them. The modin repeatedly wipes himself clean of the cape's pollution. ["The modin acts like he knows the tandak is forbidden."] Finally the modin, smiling sinfully, agrees to dance. But now he must place money in the dancing girl's bosom. Painfully, he reaches in his pocket, hating to part with his money. Finally he comes up with a tiny sum which he angrily thrusts at the dancer. Now he begins to dance, smiling. ["Later he will hear the sound of the bedug (drum beat at the mosque at prayer time)."] And indeed, the modin now hears it. Straightaway he feels a desire to pray. ["Funny, this character dances in the mosque. He uses the mosque as a place to beat the gamelan." Someone else comments, "A poor outfit this Mari Katon. They're really kasar."]

Pak Sakera appears, walking in from the back of the auditorium, down the aisles, flanked by his wives. ["What's this! Pak Sakera, the murderer! Where did he come from?"] Pak Sakera's Achilles' heel is his love of dance. The dance-party has lured him from his hiding place. He takes the floor, 
dancing with the girls and Jasit, all doing a relaxed, slow, stylized walking motion, with arms stretched out horizontally. Suddenly, Jasit kicks out his foot in a silat (karate/dance) gesture. The gamelan shifts to a loud, thundering drum beat. Sakera and Jasit jerk off their coats, and Jasit rolls his sarong up to his waist. Pak Sakera whips out his knife; Jasit dodges. Pak Sakera lunges again and again, but Jasit evades him. Suddenly Jasit pins Sakera down, and the whole crowd at the dance falls on Sakera, even Bakri joining in the mob. [A spectator cries, "Hey! Come on! Get away now or you will be done for, Sakera!" But it is the end.]

\section{Sarip Tambakjasa}

[As performed by the ludruk troupe Massa at the THR theater on February 14, 1963.]

[Just before the curtain rises a woman asks, "What story is this?" A man replies, "Sarip." The woman: "Oh God, now my son will be imitating Sarip!"]

CURTAIN RISES FOR FIRST SCENE. An assistant wedana is at his desk, a lurah on either side of him. It is during the early twentieth-century period of Dutch rule. The assistant wedana asks the lurah how they are. They say they are pleased to be present, but why have they been summoned? The assistant wedana asks them about their duties. Each answers satisfactorily. He then says he summoned them because the wedana ordered it. "At a meeting," says he, "every other wedana was praised, but ours was criticized. For one lurah has done wrong. But that lurah is not present. Where is the Iurah of Tambakjasa? Every week he is here, but not this time."

The wedana enters. Everybody stands. He speaks: "Now listen! You know you depend on the government for your living. I've been criticized at a meeting because of the state of my district. If I cannot correct the trouble I will be demoted to policeman. The trouble lies in one Iurah's area. Where is the Iurah of Tambakjasa? Covering up for Sarip? Sarip of Tambakjasa refuses to pay taxes, he steals. If he is allowed to get away with it, the whole village will do it too. What do you think of this Sarip?" One lurah, Gedangan, answers that Sarip only steals from the rich to feed the poor. [A male spectator says, "I know the man who plays lurah Gedangan. The one wearing a mustache; he's a friend of mine. I know him from Gubeng (an area in Surabaja)."] The wedana grabs the notebook of lurah Gedangan and begins beating him with a newspaper. Lurah Gedangan leaps about, trying to cover his head with his hands. The wedana calls him "stupid," and says he knows nothing but how to mess with women. Then the wedana tells the assembled group that they have two weeks to catch Sarip. If they get him, 
there will be a three-day feast. If not, they will be dismissed. "Sarip must be caught and brought here. Treat Sarip like a fish--catch him but don't get your hands wet doing it."

SCENE TWO. Sarip of Tambakjasa appears, face painted red like Pak Sakera's. He is dressed in rough village clothes and barefoot. He is a Madurese. [A man in the audience comments, "Sarip's too narrow-chested, though he's tall enough." His friend agrees, "Yes, tall enough but too small in the chest."] Sarip is about to enter the house of his santri uncle, Hadji Riduan, to ask him for money. As Sarip and Riduan talk it becomes clear that the hadji, like all stereotyped ludruk santri, is stingy and will not lend Sarip money. Hadji Riduan pushes Sarip's head and calls him lazy. Sarip is immediately enraged: "My father never touched my head during my whole life! Die!" ["Huh! The hadji pats Sarip's head!" (using a vulgar word that ordinarily refers to patting animals, not a human being).] Sarip steps forward to kill the hadji, but the hadji's servant, Paidi, a very strongly built man, stops him. Sarip leaves. Hadji Riduan tells Paidi he is his righthand man and ought to become his son-in-law. Paidi and Hadji Riduan converse. [The spectators mock the hadji's speech, especially when he says, "haram" (forbidden) and shout taunts at him: "Hadji, you're a hard one!" "That hadji is decrepit!" "This hadji hasn't seen Mecca."]

SCENE THREE. Moonlight scene. Sarip walks along, dragging his sickle on the floor. ["My! The sickle doesn't bend."] Sarip meets one of the lurah who was at the wedana's meeting. The lurah tells him that he has become public enemy number one because he does not pay his taxes. Sarip replies that he does not like to pay taxes.

SCENE FOUR. Sarip's mother, old, haggard, dressed in raggedy clothes, is alone in a village hut. She soliloquizes: "Why doesn't Sarip think about me? Mothers must always worry about their sons. Everybody says Sarip is a criminal. . ." Lurah Gedangan enters, armed with sword and dagger: "Where is Sarip?" Mother: "What do you want?" ["Oh, the lurah wants to go to bed with Sarip's mother" (laughter).] Lurah Gedangan declares that he is from the government and Sarip's mother must go with him to the police. "I'm too old to walk," moans the mother; whereupon he beats her, causing her to bleed considerably. "Come on, get moving!" he screams.

Enter Sarip. He and the lurah engage in a silat duel, feinting and dodging about. Finally Sarip whips out a knife and kills the lurah, who makes a real scene of dying, twisting about and finally dancing crazily off the stage while the audience laughs.

SCENE FIVE. Sarip and his mother are walking along; they meet another lurah, who asks why the mother is all bloody. 
"Because Lurah Gedangan beat her," replies Sarip. The Iurah then ascertains that Sarip has murdered Lurah Gedangan. He offers to "help" Sarip by taking him to the police, where "everything will be fine." Sarip engages this lurah in a silat fight and kills him too. Like Gedangan, the lurah makes a comedy of dying--cavorting off the stage and screaming "Aiiiiiiiiii!" as the audience laughs.

SCENE SIX. After an abortive raising of the curtain while the stagehands were still fixing the set, which evokes insulting laughter from the audience, the scene opens in the living room of Sarip's santri elder brother, Mualim. Sarip is at the door with his mother, who is still spattered with blood. Mualim becomes hysterical upon glimpsing the mother: "Did you beat her?" he asks Sarip. Sarip stands with eyes looking at the floor while Mualim shouts accusations. Finally the mother tells what has happened. Upon hearing of the murders Mualim frantically repeats some Arabic words as if to exorcise the sins that have been done. Sarip insults him, telling him to go do his prayers. Mualim retorts that praying is good for people: "Look how smooth the face of someone who prays is." Sarip says that is because such a person bathes so often. At this, the brother rolls his sarong up to his waist, prepared to fight Sarip, but first he stops to pray a bit--eyes uplifted and hands folded. The mother moans in fright at the incipient battle, but Mualim's wife steps in and prevents the fight. Sarip continues to insult his brother's religiosity, which evokes more prayers from the brother.

Now Sarip prepares to go. His mother asks, "Sarip, do you have the heart to leave me?" Mualim mutters more Arabic words and says, "There's always trouble." Sarip gets on his knees and embraces his mother's skirt while she begs him not to mix with the village girls. Sarip leaves, as his mother groans that she cannot eat or be happy with him, and Mualim laments that his mother loves Sarip the rogue and not Mualim the believer. He tells her that his house is her house, but whispers to his wife, "She could die, for all I care." Then he dashes off to get medicine for fear that his mother will die. [The audience laughs.]

SCENE SEVEN. Sarip, alone by the moonlit sea, soliloquizes, wondering where to go. Hadji Riduan's beautiful daughter, Saropah, who has been kept inside her father's house until the age of fourteen, appears, modestly wearing a shawl about her head. Sarip greets her flippantly: "I've just been hanging around, waiting for you." He tells her his mother is hurt. She says he had better get some medicine, but he replies that it's money he is after and asks her to give him some. She refuses, so he repeats his request, begging. "Okay, twenty-five rupiah," she says, "but my father says I must be careful about spending money. No more than thirty rupiah a week (a tiny sum). He may be a bit fishy about making his money, but at least we're living 
well--not like you." Sarip repeats his plea for money. "I have no money," says Saropah. Sarip grabs her. [The daughter of a hadji may not be touched, so the audience laughs loudly as Sarip grabs her.] Hadji Riduan's servant, Paidi, emerges from the woods at this points and steps between Sarip and Saropah. "You always get in my way," says Sarip to Paidi. "I serve the hadji and Saropah," replies Paidi, "You can tease the other girls, but not my mistress." Sarip and Paidi engage in a silat fight; Paidi defeats Sarip and hits him over the head with a board, knocking him cold. Paidi and Saropah leave. Sarip wakes up, looks around dazedly, and says of Paidi, "I don't even know his name. Is he a man (as opposed to a spirit)?"

SCENE EIGHT. Meler and Arik, two clowns, dressed as village watchmen, are making their rounds, each beating a rhythm on a bamboo tube. [A child in the audience is beating the same rhythm on a piece of wood.] Meler, who is skinny and awkward, with an eager, mouth-open stance, invariably hits one beat after Arik has finished, causing Arik to get angry. Arik, rather handsome, but with a sneering expression on his face that is accentuated by his make-up, is proud of his skill and undertakes to teach Meler how to beat the bamboo. Each time Meler tries he hits an extra beat. [The audience laughs loudly.] Arik gets madder and madder until they finally give up this routine and go into a dance, Arik varying the beat in fancy ways and hitting the bamboo sideways with a glancing blow instead of straight-on from above. Meler skillfully imitates. Meler gets a laugh by suddenly suggesting, "Let's go stealing!", and this signals a shift into a new routine.

Arik asks Meler what he will do if Sarip, the fugitive, appears. Meler boasts that he will catch Sarip, and he begins, with great vigor, to demonstrate how Sarip lost his fight with Paidi. Meler flails at the air like a drunken man, miming Sarip, then imitates Paidi waiting for the kill. Arik, the cool one, subtly tries to inform Meler that someone is watching. Meler doesn't get the hint, thinks this is an encouragement of some kind, and he repeats his act with embellishments and added vigor. "This is the way Sarip was . . ." and he portrays a drunk again. Again Arik tries to signal the presence of an observer. Again Meler interprets the hint as encouragement and repeats his act. [This sequence is repeated several times, audience laughter constantly increasing in volume.] Finally, Meler, reaching his climax, points; his eyes follow the line of his pointing finger, alighting on the lower part of Sarip's body. Slowly Meler's eyes rise toward Sarip's. Meler's smile fades. Instantly he tries to reverse his portrayal, showing Sarip winning.

Sarip says: "What were you saying about me?" Meler says, "I was speaking of the other Sarip." "Which Sarip?" "Tiny, tiny Sarip," says Meler in a high voice. Meler and Arik make a move to sneak away, but Sarip calls them back and asks, "Who has cigarettes?" "He does," says Meler, pointing to Arik. Arik, standing shoulder to shoulder with Meler, sneers over his 
shoulder at him and says, "He does." Sarip grabs Meler by the throat and lifts him high so his tongue sticks out: "You got cigarettes?" "No," says Meler. Sarip's knife comes out, causing Meler to produce cigarettes frantically. The same sequence produces matches. Now Sarip leaves, while Arik and Meler sneak away backwards, beating their bamboos in time with each step, and in such haste that they bump into each other.

SCENE NINE. Sarip and Paidi meet again and Sarip challenges Paidi. They fight, silat, and Sarip kills Paidi with his knife.

SCENE TEN. Meler and Arik come upon Paidi's body. They run off, beating their bamboos and screaming, "It's Paidi!" [The spectators laugh.]

SCENE ELEVEN. The lurah of Tambakjasa, in his office, is saying that Sarip is always a worry. Meler and Arik burst in screaming, "Lhaaaaaa, Paidi is dead!" ["My goodness, a lurah is greeted with 'Lhaaaaaa!"] Now a joke ensues, turning on an ambiguity of Javanese grammar. "Paidi killed!" shout the clowns. "Who killed (him)?" asks the lurah. "Paidi," reply they. "Then who (is) killed?" "Paidi." Repeat. Each time the lurah writes Paidi's name down in his notebook twice. Finally, what happened becomes clear, and Meler and Arik inform the lurah that Sarip threatened to "suck his head." A discussion develops about how to catch Sarip. They argue about who will approach Sarip. Finally Meler tells the lurah, "You don't dare, I don't dare... YOU (very fast)." [Laughter.] The lurah says, "I've been a coward from birth." Then he decides they should all go to Sarip's house. "If sarip isn't there, that will be fine. We'Il just look around. If he is there, we've stuck our neck out and may get it chopped off." [The audience repeats "chopped off" in the tone the Iurah used.]

SCENE TWELVE. Meler, Arik, and the lurah go to the police station. Meler and Arik squat on the floor as the lurah reports their plan to the mantri polisi, who says Sarip is probably where his mother is, at Mualim's house. Therefore, they should burn the house down, forcing Sarip to emerge.

SCENE THIRTEEN. Sarip's mother and Hadji Riduan's daughter, Saropah, sit together at Mualim's house. The police burst in, armed with guns. They inform Mualim that Sarip's mother will be bait to draw Sarip to the house, at which point the police will bum it down. The Dutch government will repay Mualim for his loss. The mother weeps. Sarip appears; he fights Mualim and Mualim kills him. The story ends with Sarip's mother standing beside his body. (In other verions, Mualim shoots Sarip with silver bullets that he has made super-potent by means of a prayer to Allah--but Sarip's mother revives Sarip by screaming until the Dutch police muzzle her, after which Sarip dies in agony.) 


\section{Untung Surapati}

[As performed by the ludruk troupe Mari Katon at the BPRI theater on June 25, 1963.]

[Just before the curtain rises the announcer states that the night's story will be "Untung Surapati," and some spectator shouts, "Come on! Tomorrow let's have 'Sarip!' It's livelier than 'Untung Surapati!'"]

CURTAIN RISES FOR FIRST SCENE. Untung Surapati, dressed in a sarong, talks of his Balinese mother--he is part Balinese, part Javanese--saying that when she was pregnant she foretold that her child would be her enemy.

SCENE TWO. Dojo, a servant, is shown in the home of his Dutch master, Tuan Mok. He says Tuan Mok married a Javanese woman who gave birth to a daughter, Susanna, but died when Susanna was seven. After that Dojo was put in charge of Susanna. As Dojo dusts the furniture, he sings a song about the beautiful girls of Solo.

Enter Susanna, who (though this is supposedly the late seventeenth century) is clad in skirt three inches above the knee, dark glasses, and a shoulder-strap bag. Susanna and Dojo engage in a brief conversation about whether Dojo can speak Dutch, after which Susanna exits.

Dojo talks about how he is enchanted with Susanna's beauty, that men kill themselves over girls like that by dashing in front of trains. Susanna re-enters, saying that Untung Surapati, her father's stable-keeper, was supposed to bring her from school, but he forgot. Tuan Mok appears at the door. [A spectator addresses Dojo: "Oh blast. Your master's coming."] Tuan Mok, in a star-studded uniform, enters. Dojo greets him, "Aftemoon, Dad!" ["The master is made fun of!"] Susanna tells her father about Untung forgetting to bring her from school. The father summons Untung, who explains that he was too busy to fetch Susanna. He goes back to the stable, Susanna tagging along behind. Dojo follows her while waving to the father and saying, in mockery of a Dutch greeting, "Dadadadadada!" [This utterance evokes the response, "Diantjuk." Some spectators comment on Susanna and Untung's relations, saying "Susanna doesn't want to stay home," and yelling, "You are lovers!" at the two, while somebody else speculates that "The servant is actually an informer for his master."].

SCENE THREE. Untung is in the stable. Dojo enters, Susanna following. Untung asks Dojo why Susanna is with him. Dojo says she just wanted to come. Susanna whispers to Dojo that she is in love with Untung and "if you will be the gobetween and still keep the secret, I'Il give you one hundred 
guilders." [A spectator yells at Susanna, "Good luck, shameless!"] Dojo agrees, and Susanna stands in a dark corner while Untung is told the secret. Untung, a slightly greasy, narcissistic type, does not appear excited, but he asks Dojo to keep watch while he makes love to Susanna. Dojo exits, muttering, "And all the time I thought she was in love with me." He then interrupts the lovers a few times just for fun. Finally Susanna bribes him to leave them alone. After Dojo is gone, Susanna asks Untung if he loves her. He says he does not know, because he's Indonesian while she's Dutch. Susanna (played by a lightskinned youth from Sumatra of Japanese-Chinese parentage) makes a fiery speech about how nationality makes no difference when a couple is in love. [The audience applauds--such a speech being the only ludruk action which always evokes hand-clapping.]

Enter two Dutch soldiers, catching Susanna and Untung in the act. They ask Susanna why she dares approach Untung. She tells them she has her father's permission. One soldier, named Herman, reminds Susanna that he and she will soon be married. She tells Herman she doesn't love him. Herman and his friend knock Untung around ["Ow!"]. He lies sullenly and passively on the ground, while some spectators imitate the soldiers' dialogue. Suddenly Susanna's father appears. ["Oh damn (blahen)! Susanna's father's coming. Go on, don't take so long. Do something with that girl!"]

Herman tells Susanna's father that Untung was making love to Susanna. Untung says it was just the reverse. The father denies this and says that Susanna loves Herman and will soon marry him. ["Susanna will get married to the short soldier!" "She doesn't want him."]

SCENE FOUR. The clown, Slamet, speaking Dutch, says, "Good evening, ladies and gentlemen. My father comes from Modjopahit, my mother comes from Modjopahit, my descendants are pahit-pahit (very bitter)." A Dutch soldier enters in order to teach Slamet, a Javanese in the Dutch army, how to march. Slamet misses a command and forgets to speak Dutch, saying in Javanese, "Apa (what)?" When he is commanded to count in Dutch he quickly gets to ten, but then forgets and slips in the Javanese "ten" in place of the Dutch. Now Slamet marches in place. The Dutch soldier then leaves, at which slamet grins--he has a huge mouth-and saucily swings his buttocks from side to side.

SCENE FIVE. Untung, alone, is saying, "Susanna caused me to lose my job. I'd like to kill her."

SCENE SIX. Susanna, alone, sitting on a trunk, weeps. Untung enters unnoticed, draws his knife and prepares to stab Susanna, but finally hesitates. Susanna turns, sees him, tries to embrace him, but he shoves her away. She kneels before him and asks him to go ahead and kill her, "for I love you and want 
to be your victim." Untung breaks down, takes her hand, and asks her if she loves him.

Enter Herman: "You are a real dog, Untung. This is the second time I've caught you." Susanna's father is called in. Untung is handcuffed and dragged away, while Susanna screams, "But it was I who was wrong!"

SCENE SEVEN. A thin fellow with a spear and shoulderlength hair stands in a forest, saying, "I am surapati, adopted son of the King of Tjirebon. My father has ordered me to help any man travelling in the forest who asks my aid."

SCENE EIGHT. A Dutch prison. Two guards enter, one being Slamet, the other a Dutchman. Slamet commands two inmates to call him "Mr. Slamet." He marches around flexing his muscles and pointing his gun. ["Big deal, that guard, the way he puts his gun on his shoulder."] The Dutchman asks the inmates what they wish to eat. They yell "Bread, bread (i.e., Dutch food)!" He returns, bringing shoes for them to shine. As they start shining, he pokes his own shoes in their faces, commanding them to shine these first. The guards then exit, and Untung enters, wearing a prison uniform, saying he has been here one and a half years. He persuades the other prisoners to help him lead a rebellion against the Dutch. When Slamet re-enters, they kill him, and flee. ["Done, 'Tung (nickname for 'Untung'). Go ahead run. You'll still get caught."]

SCENE NINE. Gunshots are heard as Untung and his fellow prisoners dash across the stage, pursued by Dutch guards. The prisoners separate, Untung going to Tjirebon to seek the King of Tjirebon's help against the Dutch.

SCENE TEN. Surapati and Untung meet in the forest. Untung asks Surapati for his help, stating that it is rumored that the King of Tjirebon also opposes the Dutch. Surapati challenges Untung to a duel, warning him that his sword is holy and will probably kill him. Untung stands and Surapati thrusts with his sword, but Untung's spiritual power is such that he cannot be harmed. Now it is surapati's turn to stand and be thrust at (this is the way all duels in the "classical" Untung Surapati and Sawunggaling stories are carried out). In the end Surapati flees in fear. ["Untung is invulnerable!"]

SCENE ELEVEN. Surapati dashes on-stage, shouting that Untung is invulnerable. Untung follows Surapati, who is running to his father.

SCENE TWELVE. The King of Tjirebon sits cross-legged in a chair, dressed in white garments. ["This is Surapati's father; he's like a kijaji (venerated teacher of Islam)."] The king speaks of surapati, his only son, who will succeed him when he 


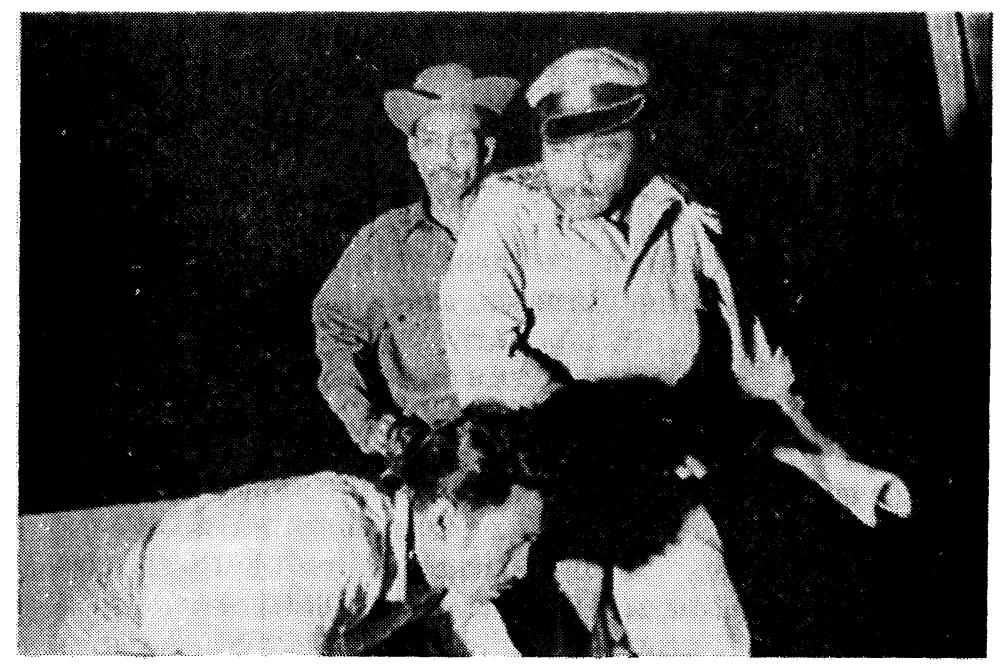

Untung is beaten by two Dutch soldiers.

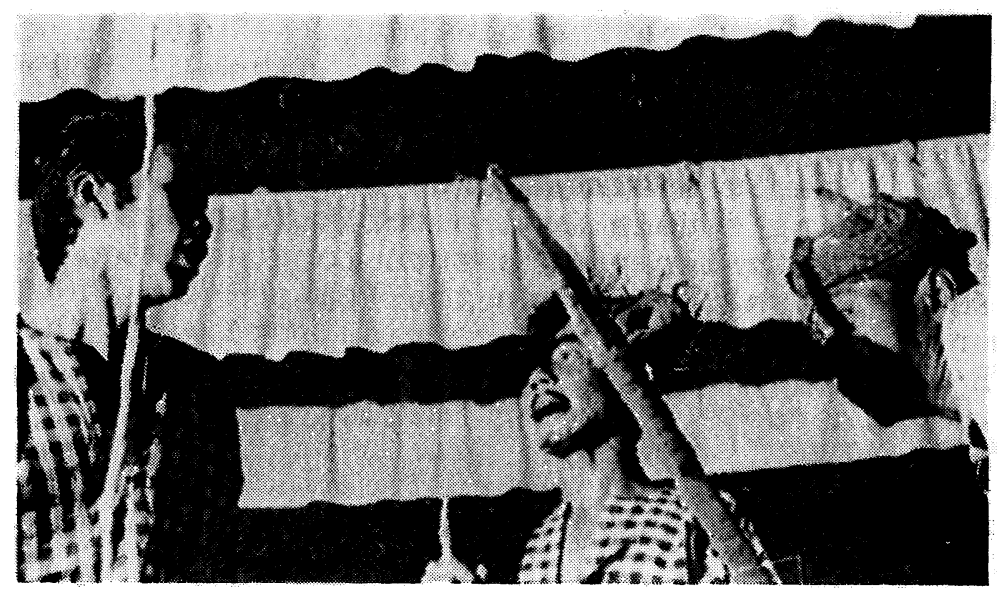

Untung's prison comrades prepare to attack the Dutch. 
dies. Surapati enters, followed by Untung. The King asks Untung why he has come. Untung tells him, and then the story of what happened in the forest is unfolded. Upon hearing this, the King takes his son's sacred sword and kills him on the spot because he disobeyed his father's orders to give aid to strangers in the forest, and because he ran. ["The son's sacred sword is taken from him by his father because he was a coward."] The King then grants Untung his son's name, so that Untung is now "Untung Surapati" and also invulnerable. ["Untung will be invulnerable."] He commands Untung to go to West Java in order to gain the support of an anti-Dutch king there.

SCENE THIRTEEN. Susanna and Dojo are walking, seeking Untung Surapati, since Susanna is with child. Dojo asks her, "How many kilos do you weigh now?"

SCENE FOURTEEN. Untung and his former prison comrades meet. They decide the time for rebellion has come.

SCENE FIFTEEN. Dojo and the prison escapees meet. The fugitives take Dojo and Susanna to Untung Surapati. Susanna and Untung meet again. [A man yells to Untung: "Take her home, 'Tung. Her father will be looking for her!"] Untung advises Susanna to go immediately to Holland and name her child "Walter Robert." ["The child will be called 'Robert." "] Untung tells his comrades that he made love to Susanna before he began to fight the Dutch.

SCENE SIXTEEN. Susanna's father and a Dutch soldier are making arrangements for various Netherlanders, including Susanna, to return to Holland.

SCENE SEVENTEEN. Pangéran (prince) Purbaja of Bandung is in his living-room talking with his daughter Sitji. Susanna's father, Herman, and another Dutchman enter to ask Purbaja's help in capturing Untung. ["Just a kampung Dutchman!" shouts a spectator, remarking on the non-Dutch appearance of Herman.] Purbaja agrees to help; in return, the Dutch will give him a higher rank. After the Dutch leave, Purbaja asks his daughter to seduce Untung, thus leading him into a trap.

SCENE EIGHTEEN. Untung and Sitji meet. She becomes genuinely attracted to him and reveals the plot against him, saying that she hates the Dutch. ["She even tells him he'll be arrested." "This kid likes Untung." "She flirts when she talks."] Purbaja enters and tries to convince Untung to stop fighting the Dutch. Untung refuses. Purbaja then tells him he must surmender and tries to stab him. Untung, however, stands still, and his spiritual power prevents Purbaja's dagger from penetrating. Purbaja flees in fear, while Sitji tells Untung she loves him. 


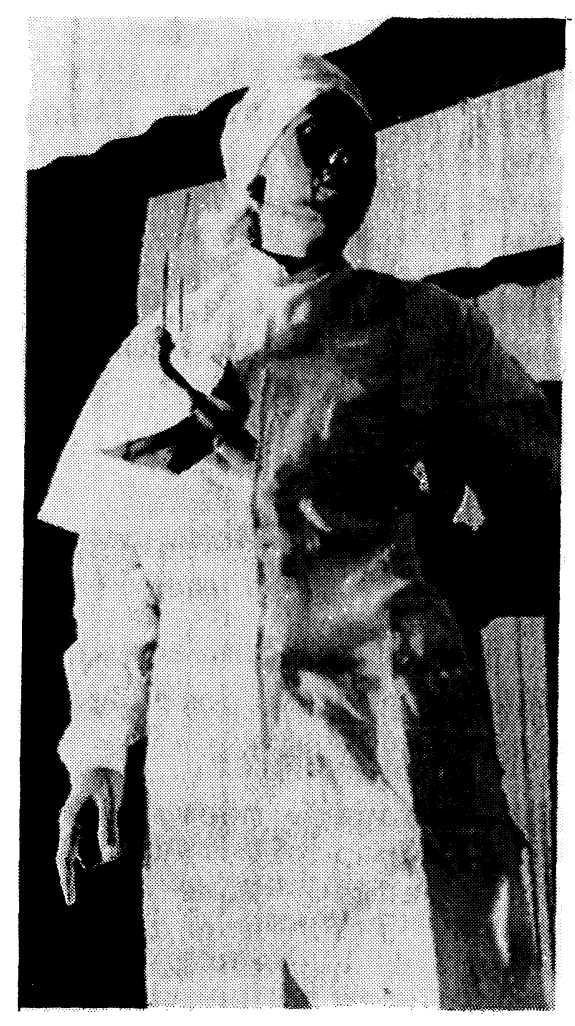

The King of Tjirebon prepares to kill his son.

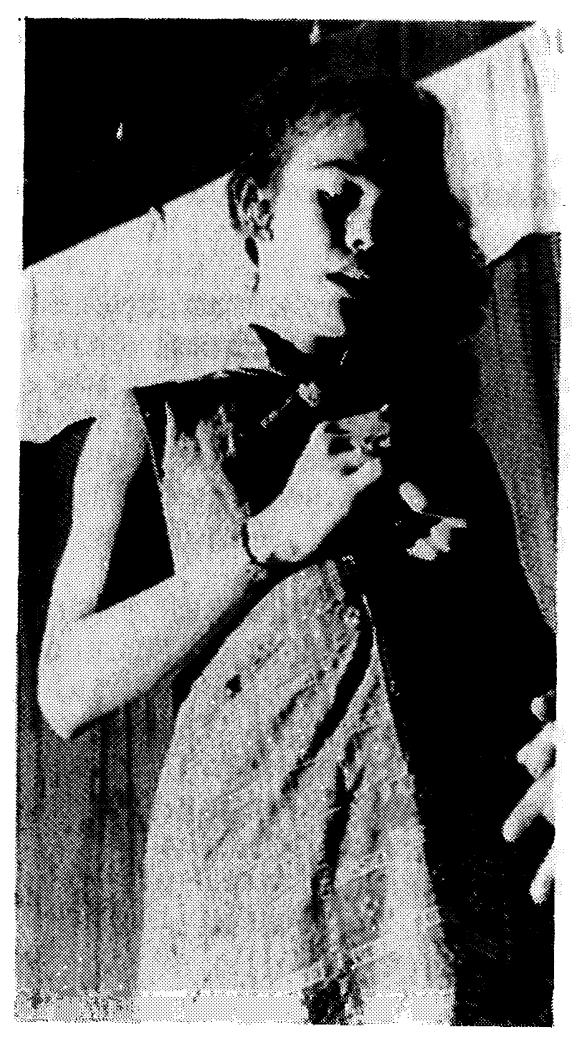


SCENE NINETEEN. Untung and his two prison comrades meet in the midst of battle against the Dutch. One of the fugitives offers to exchange clothes with Untung, since his life is less valuable than Untung's and he knows the Dutch will be hunting for him.

SCENE TWENTY. The man clad in Untung's clothes rushes into battle and is shot by the Dutch. Coming triumphantly to claim the body, they now realize it is not Untung's.

SCENE TWENTY-ONE. Untung and the other ex-prisoners come out to look at the body of their dead friend. Untung, standing over the body, pronounces him a hero. The story closes. [In another performance of "Untung Surapati," the story-line was rather different: there were many scenes showing the Dutch trying to trick or kill Untung, and the spectators were much more violent against the Dutch figures, shouting things like, "Ah, you're slippery!" and encouraging the hero: "Untung, don't give in. Just kill that Dutchman!"]

\section{Sawunggaling}

[As performed by the ludruk troupe Mari Katon at the PBRI theater, August 6, 1963.]

THE CURTAIN RISES FOR THE FIRST SCENE. It is the late 1600's. The Adipati (lord) of Surabaja, Djajengrana is at his mountain palace, Wlidah, with his mistress, Sangkrah, a girl from the local village. [Upon glimpsing their regal style of clothing, several spectators comment that "They're dressed like a bride and groom!" which is true, since Javanese wedding costumes are patterned on ancient royal dress. One man asks, "Did you borrow that head-dress or steal it? You're too poor to buy it! What is this, brother?" Another comments on the inappropriateness of the decor: "My goodness, the palace has electric light!"]

Suddenly the Adipati is summoned to Surabaja to join neighboring Pasuruan in defense against the Dutch East India Company. Since his mistress is a villager of Wlidah, he decides to have her return home. She kneels at his feet, weeping. He gives her a piece of cloth as a remembrance of himself and tells her that any offspring she bears (she is pregnant by him) will be recognized as his if they carry that cloth. He asks that the firstborn be named "Djoko Bereg."

SCENE TWO. A peasant man, father of Sangkrah, sits at a table in his hut at Wlidah. Sad and haggard, he mutters, "I married only once, but I'm unhappy. Twenty-five years of quarrelling. She's at the market from seven in the morning till half past three in the afternoon. Does she sleep there?" The 
wife enters, a strong, man-eater type, bigger than her husband. She speaks in a harsh, shrill voice: "If I smash you to the ground, what'll you do about it? Have you eaten? Do you ever bathe? You've slapped me four times since we've been married. Do I live with a husband or a Japanese? Why are you always jealous?" The husband whiningly asks her why she comes home at 3:30 P.M. instead of 9 A.M. like other women. He tells her it's fine for her to make up her face, but why doesn't she bathe sometimes as well. She: "If I didn't make up my face, you'd get sick. You can't satisfy my needs because you aren't a real man. You broke your leg playing soccer (probably alluding to impotency). Why don't you retum me to my parents?" [A man says to the wife, "You're so hard, older sister. How about a little patience?" Another spectator says of the wife's shrill voice, "It suits her." Several persons comment that the couple are "like Madurese."]

Now the couple simmer down and decide to talk about old times when they were young. "Let's talk about the children," says the husband. "Where's our daughter? No trace of her for months." At this moment Sangkrah, the daughter, enters. Father: "O she's beautiful." Mother (to Sangkrah): "Your father is hot for you." Father: "I'm married to Pak Sakera."

Then the father perceives that the daughter is pregnant; she covers her stomach with her bag in shame. He is shocked, looks at her, then away, then back again. She kneels and asks forgiveness. He hits her and kicks her. ["It's a shame to treat your kid like that." "She dares do it but she's ashamed and covers her stomach. It's pretty clear to her folks that she's pregnant." "The kid disobeyed. She fooled around, got herself pregnant." "She's pretty, sells it cheap."] The husband says that he was once a lurah, but now his daughter has ruined his name. The wife protests that he is unjust. Her husband kicks her. The wife grabs him around his knees, and then from behind, holding him down so he cannot use his knife. Finally, the daughter manages to tell the father that it was the Adipati who impregnated her. Now the father is sorry. He kneels at his daughter's feet to ask her forgiveness. [A man addresses the father: "Huh, too late pal (tjak)!" and a woman tells him, "Next time, don't be in such a hurry," while another man exclaims, "Pregnant by the Adipati of Surabaja! What do you make of that?"I Now the wife takes a sickle and chases the father around the room. Suddenly the daughter goes into labor. Father and mother dash for the midwife.

SCENE THREE. Eight years have passed. Two boys appear, dressed as princes; they are sons of the Adipati. One of them is played by a man who usually takes "tough female" parts like Mbok Sakera.

SCENE FOUR. At the peasant cottage in Wlidah, Sangkrah's 


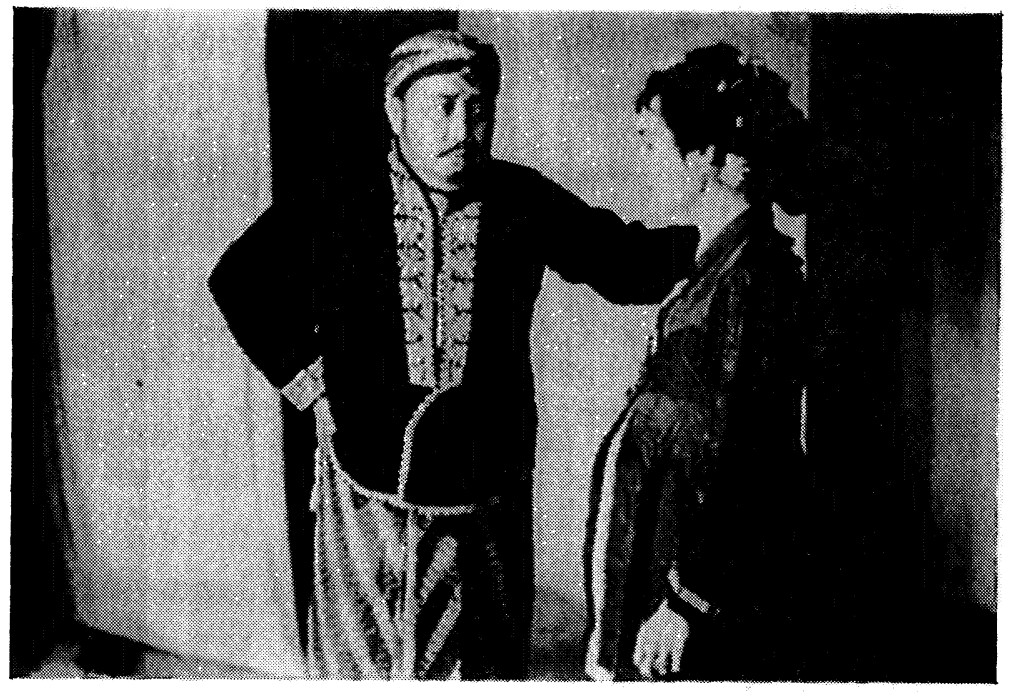

The Adipati of Surabaja bids his mistress farewell.

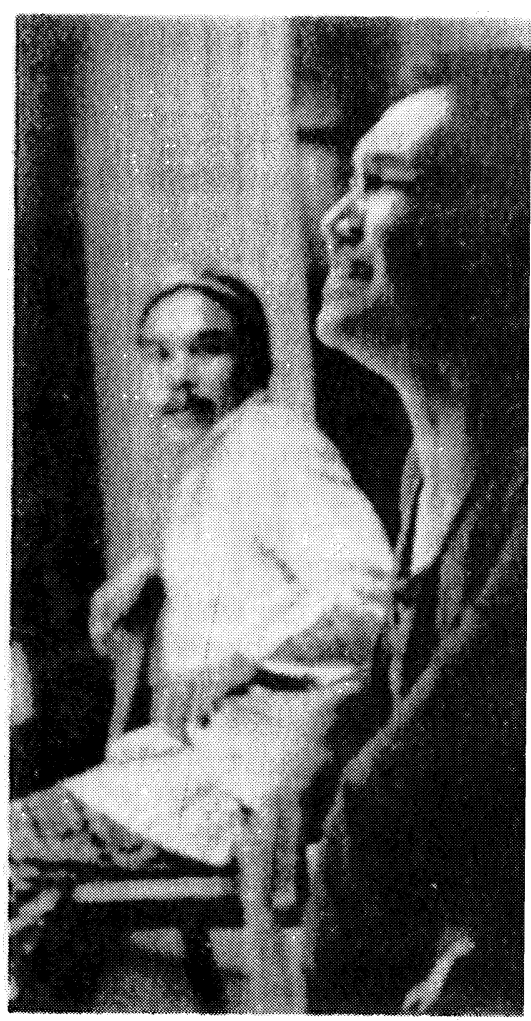

Sangkrah's parents al

Djoko Bereg, with his cock, prepares to leave his grandparents (kampung Independence Day performance, 1963).

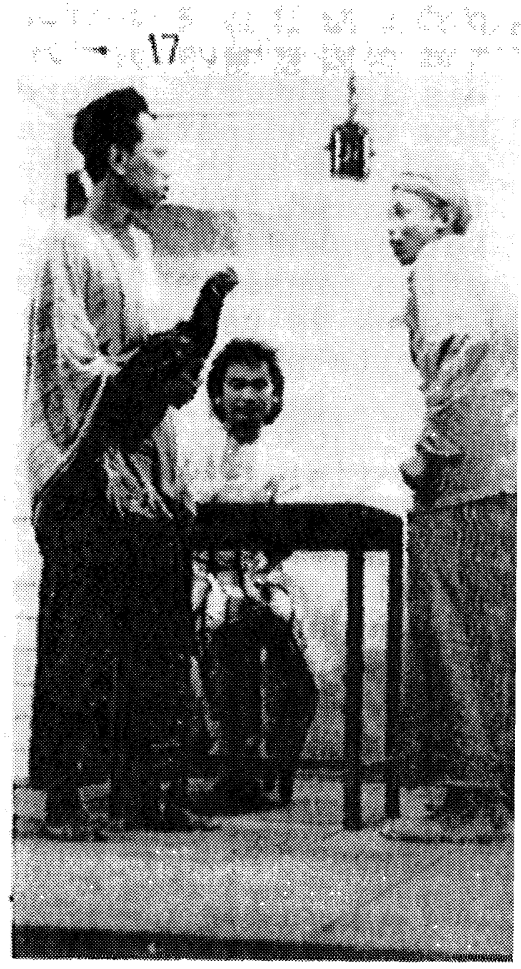


son Djoko Bereg enters ["Oh, here comes the kid."] He announces, "I'm sad because I have no father." Djoko's grandfather, played by Amat the clown, says he's Djoko's father. Djoko denies this, saying that he will die if he does not see his father. His mother tells him that his father is the Adipati of Surabaja and shows him the cloth given her by the Adipati. Djoko asks her permisgion to seek his father and leaves, taking the cloth. Amat decides to follow the boy. The grandmother (played by a comic transvestite called "Djali") pats the grandfather on the head--a vulgar gesture--and says she loves him.

SCENE FIVE. Djoko Bereg, anmed with the cloth and his cock, with which he has won many fights, meets the two princes of scene three. Djoko has not learned how to speak krama (refined) Javanese because he has had no father to teach him, and so he speaks disrespectfully to the princes. [A woman exclaims, "Boy, he acts like a bum." A man tells Djoko, "'Reg, these are your brothers!"] The old grandfather toddles up to smooth things over, making jokes about Djoko's name meaning "smell of the bathroom." Djoko and the princes decide to let their cocks fight. Since Djoko has no money, he agrees to give his life if he $108 e 8$. The princes will pay 10,000 rupiah if he wins. They fight, and Djoko's cock wins. The princes refuse to pay. Djoko hits them. Princes and cock run away, Djoko chasing. [Suddenly the cocks, which are alive, get away, to the delight of the spectators. A woman yells, "0 the rooster got away!" and a man says, "Hey, that's the way!"]

SCENE SIX. The Adipati's palace in Surabaja. A guard, Amari (a clown), is standing there, dressed strangely--no shirt, cone-shaped hat--and saying, "I stole and sold Amat's cow in order to buy a uniform and become a palace guard--a member of the civil service!" Amat enters, sees Amari, and cannot conceal his laughter: "Where's my cow? Why don't you wear a shirt?" Now the Adipati himself walks by. At the sight of him, Amat explodes into laughter, holding his mouth shut so that he makes the sound "Psssssssst." "He looks just like a character in ketoprak!" shouts Amat. (Ketoprak is a folkplay genre which often presents "classical" legends like "Sawunggaling" whereas ludruk is usually set in contemporary times except for the tjerita pahlawan.)

Djoko appears, accosts the Adipati's sons, and defeats both in a fist-fight. The Adipati, hearing the noise, strides grandly up and speaks to Djoko and his grandfather: "You are low people. Why do you cause trouble?" Djoko replies in ngoko (low Javanese). "I can only speak ngoko because I had no father to teach me krama. I seek my father." [Now the audience becomes quiet, listening eagerly. Djoko has his hand stretched out tensely; Amat chatters on about Amari taking his cow.] Djoko draws out the fine cloth given him by his mother. When the Adipati sees it, he stands still and quiet, as if a long-forgotten memory is 
returning to him. The gamelan plays a very soft and sweet melody. The Adipati says to Djoko, "Now I remember. This is the cloth which I gave away many years ago." Djoko starts to put the cloth back in his sarong. The Adipati continues, "Do not put it away. It is mine. You are my son. I am your father." He brushes Djoko's hair back and Djoko embraces him around his knees.

Now the Adipati introduces Djoko to the two princes, telling them Djoko is thein brother, and asking them to teach Djoko all they know. He asks Djoko what he should be called. Amat shouts raucously [to laughter from the audience] "Just call him 'Guk!"" (Apparently this is a low village name.) Djoko says his name is "Sawunggaling." "Sawung" means "cock" and "galing" means "a powerful element." The Adipati is pleased at his choice.

SCENE SEVEN. Amat, as Sawunggaling's grandfather, has been given a high place in the palace. He is elegantly dressed in satin clothes and relates that people now kneel before him wherever he goes. "Maybe I'll become an idol." He commands the guard, Amari, to kneel in his presence. Amari follows him out, duck-walking.

SCENE EIGHT. Dutch soldiers and women appear, the women in evening dresses, the soldiers clad in modern Indonesian army fatigues and helmets, though they are supposed to be with the Dutch East India Company in early 1700.

SCENE NINE. Sasraningrat, Adipati of Semarang, appears, revealing that he is jealous of the Adipati of Surabaja and wants to help the Dutch against him so he can gain his position. [As Sasraningrat speaks, lamps in the theater are switched on and off, throwing shifting shadows on the curtains and evoking the response--aesthetic in character, as are occasional ludruk audience responses--"Very nicely done, those shadows."]

SCENE TEN. A Dutch soldier strides across the stage, counting in Dutch, but belting out a raucous Javanese "ten" when he hits that number, thus revealing that he is actually Javanese.

SCENE ELEVEN. A tournament is being held at Kartasura, capital of the Kingdom of Mataram. All of the Adipati's sons are taking part. The Dutch have promised to give food to the hungry masses if one son can shoot an arrow through a distant string from which is suspended a cloth. Each son tries and fails. Sawunggaling, still dressed in peasant clothes, arrives late. He is told by the Dutch that he will die if he fails. He breaks his bow but still manages to hit the string. He is acclaimed a hero, congratulated by the Dutch, appointed successor to his father, and given in marriage the daughter of another regent. Sasraningrat and the Dutch arrange a party to celebrate Sawunggaling's marriage. At the party Sawunggaling's father is 
poisoned, leaving Sawunggaling responsible for the fate of Surabaja. (This concludes the first night's performance; the following scenes occurred the next night.)

SCENE TWELVE. Sawunggaling, now with long hair, winged headdress, dagger, tight black breeches, and no shirt, dances out in wajang wong (classical dance drama) fashion, followed by his old peasant grandmother, padding along, looking for Amat.

SCENE THIRTEEN. Amat appears, dressed in his satin costume. He suddenly collapses in mirth at the thought of himself dressed as he is, and says, "I even get to carry a parasol!" The grandmother trots in, kneels respectfully before this figure. Amat talks to her in pompous Javanese, using the courtly intonations of ketoprak. Suddenly he whips off his hat. The grandmother recognizes him, screams his name in a shrill fishwife's voice. She shoves him affectionately; he kicks her lovingly. They start jabbering away in crude language.

Sawunggaling and his wife appear. He recognizes his grandmother, embraces her in elevated, stylized fashion. She kneels, but he makes her stand. She waddles out, still bent at the waist, parodying a respectful posture, as the audience laughs.

SCENE FOURTEEN. Sawunggaling has been requested by Sasraningrat (at the suggestion of the Dutch) to seek and kill a certain Islamic missionary from India, now living at Gresik. Sasraningrat says the Dutch fear Islam will grow too strong, and if Sawunggaling can kill this man the Dutch have promised to give him his rightful title, "Adipati of Surabaja." Sawunggaling prepares to go. He bids his grandfather farewell, sadly kneels (sembah) before his grandmother, embraces his wife in elevated fashion, and then leaves.

SCENE FIFTEEN. Sawunggaling, assuming a wajang wong "classical" stance, stands with heaving chest, stroking his hair, throwing out challenges to the left, then turning and repeating the performance while facing right.

SCENE SIXTEEN. A woman dressed in a long pink dress appears before Sawunggaling as he wanders through a woods. She is an evil love goddess. Sawunggaling tries to kill her but his spear bends. She is invulnerable. She offers to help him, and in order to do so she enters his body (this is represented by her dashing off as red lights flash on the dark stage).

SCENE SEVENTEEN. The Islamic missionary who is Sawunggaling's target walks alone, dressed all in white, wearing a turban. The set is dark, but with flashing red lights. Sawunggaling enters, attempts to kill the missionary, but in spite of great efforts cannot succeed. His spear simply bends. Sawunggaling thereupon kneels at the man's feet. The missionary advises Sawunggaling to return to Surabaja and fight the 
Dutch, who are trying to overpower his people. He promises to give Sawunggaling magical strength.

SCENE EIGHTEEN. Tjakraningrat, Adipati of Sampang, appears wearing a red, white, and blue medal of the Dutch East India Company. He is Sawunggaling's uncle, fat, short, and shrewd. The two fight, but neither can prevail. Sawunggaling finally embraces his uncle's knees, weeping. Tjakraningrat advises him to avenge his father's death at the hands of the Dutch by conquering them. Sawunggaling agrees.

SCENE NINETEEN. The two brothers of Sawunggaling appear, going somewhere.

SCENE TWENTY. A party is being held by the Dutch for Sawunggaling. Four Dutch soldiers and three Dutch girls in evening dresses are present. Much wine is being drunk. Suddenly Sawunggaling appears, his clothes greatly contrasting with theirs: he is bare-chested, long-haired. He is offered the seat of honor, where he sits, stiffly, in classical wajang wong stance, spear pointed straight up. The Dutch offer him wine. He detects that it contains poison, refuses to drink it, and asks the Dutch to drink it. They refuse. He throws the poison at a soldier, killing him, and all the others flee in panic.

SCENE TWENTY-ONE. Tjakraningrat is consorting with the Dutch, jovially slapping them on their backs. Though he had been Sawunggaling's ally, he has agreed to capture him if the Dutch will award him the regency of Surabaja.

SCENE TWENTY-TWO. Sawunggaling soliloquizes, seated, with shoulders heaving, body tense, speaking in elevated ketoprakstyle language. Suddenly he dashes out, ready to kill.

SCENE TWENTY-THREE. Sawunggaling meets Tjakraningrat and tries to kill him. But Tjakraningrat's spiritual power is too great and he just laughs. Now Sawunggaling challenges Tjakraningrat to try to stab him. His uncle's knife will not penetrate, but Sawunggaling voluntarily allows Tjakraningrat to carry him off to a Dutoh prison.

SCENE TWENTY-FOUR. A soldier in Dutch uniform says, "Everywhere I go I see Sawunggaling even though he is in prison. There are thousands of him."

SCENE TWENTY-SIX. Tjakraningrat confesses that he fears Sawunggaling and that his secret yearning is to go to Holland and marry a Dutch lady.

SCENE TWENTY-SEVEN. Dutch soldiers, seeking Sawunggaling, go to his mother's rustic hut at Wlidah, and beat her. Sawunggaling catches them in the act, slaughters one soldier, then chases the other around the hut with his spear at the man's back 
while the man waves his tommy-gun wildly in the air. [The audience laughs.] Sawunggaling kills the soldier as he screams, Dead!" Now Sawunggaling turns to his mother, embracing her knees. She dies from the wounds inflicted by the Dutch. Sawunggaling grieves in stylized stance, one leg on the ground, the other kneeling, chin supported by hand. Then he rises and moves out in ketoprak dance fashion to attack the Dutch.

SCENE TWENTY-EIGHT. Dutch guns shoot. Sawunggaling stands immobile, rapidly stroking his long hair and praying to his mother. The guns have no effect.

SCENE TWENTY-NINE. A Dutch captain and three girls are talking. A voice from off-stage says that the next performance will show Sawunggaling's challenge to the Dutch. The final curtain drops. (The next performance did not continue the story.)

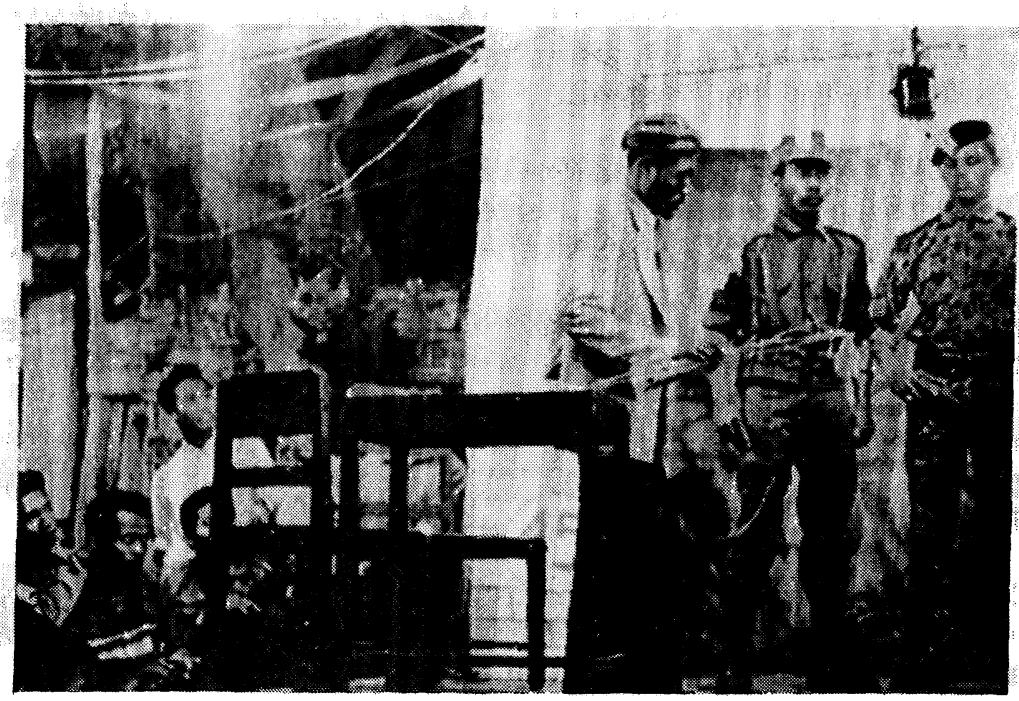

Dutch soldiers in the Independence Day performance, 1963. 